\title{
Knowledge and Awareness among interns and residents about medical law and negligence in a medical college in Vadodara - A Questionnaire Study.
}

\author{
Dr. Jasuma J. Rai ${ }^{1}$, Dr. Rajesh V. Acharya ${ }^{2}$, Dr. Deepak Dave ${ }^{3}$ \\ 1(Associate Professor, Department of Periodontics, K.M.Shah Dental College and Hospital, Sumandeep \\ Vidyapeeth, India) \\ 2(Patient Care Co-ordinator, Vaatsalya Hospital, Mysore, India.) \\ 3(Professor and HOD, Department of Periodontics, K.M.Shah Dental College and Hospital, Sumandeep \\ Vidyapeeth, India)
}

\begin{abstract}
Medicine is a noble profession but there is also growing anxiety both within the medical profession and in the community regarding increasing trends of complaints and lawsuits against doctors. Knowledge about medical ethics is as fundamental to the practice of medicine as clinical skills. The trainee period is a critical time for fostering ethical reasoning in students and hence a questionnaire based study was conducted among interns and postgraduate students of a medical college in Vadodara. The questionnaire consisted of questions pertaining to basic knowledge of medical law, record keeping, ethics, informed consent and medical negligence. A total of 300 students were enrolled for the study. Most of the students were able to answer questions about ethics and informed consent and basic on medical law. Knowledge about record keeping ( $p<0.001$ with C.I:68.68-73.9) and medical negligence ( $p<0.0241$ with C.I:61.35-64.35) was found to be significantly different between the classes of students. More efforts should be made to sensitize the students about law and liabilities related to their practice.
\end{abstract}

Keywords - Informed consent, Medical Ethics, Medical Negligence, Medico Legal Case, record keeping.

\section{Introduction}

In ancient Egypt, practice of medicine was subject to legal restrictions. The right to practice was restricted to members of a certain class, and all doctors had to learn and follow the precepts laid down by their predecessors. Obviously, this was to protect the public from quackery. Fees for the doctors were paid by the State. If unsatisfactory results followed a course of treatment that had departed from the orthodox, the doctor responsible would be liable to punishment, which could be very harsh. Similar legal restrictions on medical practice were also found in other early civilizations such as Babylon and India. [1]

Medical ethics has developed into a well based discipline which acts as a "bridge" between theoretical bioethics and the bedside. The goal is "to improve the quality of patient care by identifying, analyzing, and attempting to resolve the ethical problems that arise in practice". Legal and ethical considerations are inherent and inseparable parts of good medical practice across the whole spectrum. The disciplines of law and ethics in medical practice overlap in many areas and yet each has its unique parameters and distinct focus.

Only technical aspects have been emphasized in medical education, and paternalistic treatment has continued in clinical practice. In medical education, the amount of information learned by students has been increasing year by year, in line with scientific advances. Clinical medicine is thought to be shifting toward a patient-oriented contract, and in this model, a patient's right to autonomy as expressed by the term 'informed decision'. The importance of culture as a part of medical education has been raised and physicians' ethical views have become an issue. There is a need for skills and knowledge related to ethics, which is as fundamental to the practice of medicine as basic sciences or clinical skills. This will enhance safe health care delivery in an unbiased standardized way [2]. Courses in medical ethics are becoming an integral part of the curricula for many medical schools in Europe and India.

The trainee period is a critical time for fostering ethical reasoning [2]. The survey was conducted on awareness among intern doctors and residents during this period of transition from medical student to physician in order to gain a better understanding of the ethical sensitivity of interns and postgraduate clinical trainees in medical college in Vadodara.

\section{Materials And Methods}

Out of two Medical colleges in Vadodara one college was randomly selected. This study was conducted in Srimathi Bhikiben Kanjibhai Shah (S.B.K.S.) Medical College and Research Centre, Vadodara, Gujarat, India. S.B.K.S. is a 1000 bed tertiary care hospital; it is also a teaching hospital for medical faculty of 
Sumandeep Vidyapeeth (University). This is a self designed, close-ended questionnaire developed in English language. The questionnaire consisted of 30 questions pertaining to basic knowledge of medical law, record keeping, ethics, Informed Consent (IC) and medical negligence. The Study was approved by the Institutional Ethical Committee. Written consent was obtained after providing the information sheet to the Medical interns and residents. The study population included interns and residents of S.B.K.S Medical College. Participants who were not willing to participate in the study or who were absent during three consecutive visits were excluded from the study.

A pilot study was conducted among $10 \%$ of the study population for testing of validity and inter-item consistency of the developed questionnaire. According to "concurrent validity" method, the validity of the questionnaire came out to be $93.60 \%$. Individuals included in the pilot study were not considered for the main study to prevent possible bias. The study was conducted over a period of three months from June to August 2012.

One point was assigned for each correct answer and 0 for wrong answer. The knowledge score for the individual was calculated by summating the correct answers. Statistics used in the study were Descriptive statistics, Pearson Chi-square test, ANOVA, Post Hoc test (LSD) and p-value of less than 0.05 was taken as statistically significant. Statistical analysis was done using SPSS Version 11 software program

\section{Results}

A total of 300 participants took part in this study from various departments of S.B.K.S. Medical College. Response rate was $100 \%$. The gender and class of all the respondents are summarized in Table I. Awareness of medico-legal cases was more in interns (70\%) as compared to the other groups (RI - $44.9 \%, \mathrm{R} 2-$ $56 \%, \mathrm{R} 3-60.4 \%$ ) and $78 \%$ of participants said that they are taking special precautions while handling medicolegal cases. 94\% of respondents were able to answer to questions about record keeping but when asked about how long the records of a Medico-Legal Case (MLC) should be kept, only $45 \%$ answered correctly $(\mathrm{p}<0.00)$ (Table II)

\subsection{Knowledge on medical ethics}

More than half $(56 \%)$ of the interns were not aware of MCI Code of Ethics 2002 and among the residents R3 (85\%) had better knowledge of The Code as compared to R2 (73\%) and R1 (62\%), ( $\mathrm{p}<0.002)$. On the subject related to duties of the ethical committee all of the respondents said that they knew the role of ethical committee in the institute, $46 \%$ of them said ethical committee oversees whether all research projects are done properly, $32 \%$ saw the committee as having a role in dealings with complaints, $13 \%$ as an advisory body to the staff and $9 \%$ on disciplining of staff. ( $p<0.002$ ).

Medical students were generally very positive about the importance of ethical knowledge however 29 students said it was not important at all. The majority of respondents (63\%) replied that they acquired their knowledge during training and one-third of them (29\%) got their knowledge from lectures and seminars. $40 \%$ of participants said they would consult their head of department if they had a legal problem at work, $30 \%$ said they would consult a lawyer directly, $12 \%$ would go to their supervisor, $8 \%$ would go their friend and $1 \%$ would seek consultation from their colleagues.

\subsection{Knowledge and Awareness of Informed Consent}

Almost 90\% of the respondents were aware of informed consent and 61\% regarded Informed Consent with reasonable physician standard model as their choice. Age and mental status were considered as important factors for the ability to give consent $(\mathrm{p}<0.024)$ and $95 \%$ said that informed consent is the best type of consent for a patient undergoing a surgery. More than half the respondents (55\%) said that treatment should not be refused if the patient behaves violently $(\mathrm{p}<0.000) .90 \%$ of respondents felt that children should not be treated without parent/guardian consent except in cases of emergency. (Table III)

\subsection{Respondent's perception on medical negligence.}

When answering the questions relating to medical negligence and related affairs (Table III) $73 \%$ of respondents were aware of the meaning of burden of proof and $86 \%$ were well aware of the facts about what makes a practitioner negligent, where patient care is involved. More than $55 \%$ of the students had no idea what vicarious liability and res ipsa loquitor was. Only $57 \%$ of the participants held the nurse and surgeon responsible for leaving gauze piece in the operation site, about half the respondents knew about mercy killing, $85 \%$ of the students had knowledge about organ donation. When questioned about compensation for medical negligence case $52 \%$ of the respondents said that the patient should approach the consumer court $(\mathrm{p}<0.000)$. (Table IV).

One Way ANOVA was used to compare the knowledge among different classes and different groups of questions. Knowledge about record keeping ( $p<0.001$ with C.I:68.68-73.9) and medical negligence ( $<<0.0241$ with C.I:61.35-64.35) was found to be significantly different between the four classes of students 
(Table V and VII). Post Hoc test (LSD) was used to provide specific information on which group was significantly different from the other on the knowledge regarding record keeping and medical negligence. There was statistical significant difference between R3>I ( $<0.005), \mathrm{R} 3>\mathrm{R} 2(\mathrm{p}<0.001)$ and $\mathrm{R} 1>\mathrm{R} 2(\mathrm{p}<0.004)$ while answering the questions regarding record keeping and Difference in knowledge was seen regarding medical negligence between I>R1 $(\mathrm{p}<0.011)$ and $\mathrm{R} 2>\mathrm{RI}(\mathrm{p}<0.013)$, as seen in the Table IV and VI.

\section{Discussion}

All the interns, postgraduate students took part in the study; therefore the results can be considered to be represented of the knowledge and opinion of medical students at Vadodara at the time of the study. The response rate to awareness of MLC's was 56 percent among the participants, but when asked about precaution while handling MLC's 78 percent response rate was present, this could be due to the fact that half the students have not come across medico-legal cases but they have the knowledge about what special precautions to take while managing medico-legal cases, this could be due to their lecturers and seminars taken on the said topic in Forensic Medicine. Most of the respondents said that knowledge of ethics is extremely important and only few of them said it is not important all, their main source of knowledge on healthcare ethics was during training, and such experiences should be used to reinforce ethical knowledge and practice. This is in accordance with the study done by Dash S.K.in 2010 [3].

There was gradient wise increase in the knowledge of The Code of Ethics with the intern's knowledge being the least and the 3rd year residents being the maximum $(\mathrm{I}<\mathrm{R} 1<\mathrm{R}<\mathrm{R} 3)$. This could be attributed to the fact that R3 have more medical training than the interns. Most of the respondents have an idea about the role the ethics committee plays; about half of them said that that the committee plays a major role to ensure the research projects are conducted properly, one-fourth said that they deal with complaints and a minority of the participants said that they act an advisory body. This is in agreement with the study conducted by Walrond ER in Barbados [4] though in their study only a minority of the participants said the ethical committee had role to play in research projects.

More than sixty percent of 3rd year residents had knowledge about record keeping as to compared the other groups, this could be credited to their experience in the clinical field which is in agreement with the study done in 2009 by Makhani C.S. in Indore.[5]. Written records, including medical history, chart notes, radiographs, and photographs must be meticulous, and it is necessary for the documents to be signed and dated. Legally, physician written records carry more weight than patient's recollections.[6] Under Article $51 \mathrm{~A}(\mathrm{~h})$ of the Constitution of India, there is a moral obligation on the doctor, and a legal duty, to maintain and preserve medical, medico-legal, and legal documents in the best interests of social and professional justice.[7]

General awareness on informed consent (IC) was there among respondents with reasonable physician standard as the most popular choice. The physician authority is hardly ever challenged, and their advice is held in high esteem hence this standard is still being used even though nowadays patient's standard is becoming popular [8]. Most of the respondents regarded IC as valid and important and this is in accordance with the study carried by Heywood R. in 2007 who found that $98 \%$ of medical students found IC to be important and necessary for a surgical intervention [9]. The factors taken into consideration for a valid informed consent are age and mental status. IC requires that patient fully understand the information given, but if the patient is debilitated due to a serious illness/mental condition, a suitable surrogate should make decisions which are in the best interest of the patient, or if the patient is the child then the IC can be given by the parent or guardian except in cases of emergency [8].

There is a difference of opinion on whether to treat a patient if he/she behaves violently, about half said not to treat them and other half said they have to treat them. This confusion is because there is no clear cut law on patient's care in Indian scenario; however fundamental rights enshrined in the constitution say that patient has a right of access to health care. [10]. The healthcare worker should take reasonably practicable steps to maintain a safe environment for patients and staff in which patients can be offered treatment in accordance with the duty of care that is owed to them [10]. If violence or aggression cannot be controlled so as to provide a safe working environment, the health service's duty to staff takes precedence over its duty of care of patients. The statutory duty of care is high and breach leads to a potential malpractice case. Health care professionals and health services must work together to develop strategies to prevent and manage the risk of occupational violence. [11].

While answering questions about medical negligence the students answered them but when detailed questions were asked about various liabilities and judicial system related to medical malpractice only less than half the participants were able to answer. This indicates that the students have only a limited understanding about negligence and law and more efforts should be made to sensitize the students about law and liabilities related to their practice. Although a number of studies aimed at assessing the knowledge and awareness of medical students regarding medical negligence have been published, this is the first article of its kind that attempts to evaluate these variables hence association with the other studies could not be done. 
V. Tables

TABLE I: Gender and Class of Respondents

\begin{tabular}{|c|c|}
\hline GENDER & $\mathrm{n}=300$ \\
\hline MALE & $179(60 \%)$ \\
\hline FEMALE & $121(40 \%)$ \\
\hline CLASS & \\
\hline INTERN (I) & 54 \\
\hline $\mathrm{I}^{\mathrm{st}}$ year RESIDENT (RI) & 118 \\
\hline II $^{\text {nd }}$ year RESIDENT (R2) & 75 \\
\hline III $^{\text {rd }}$ year RESIDENT (R3) & 53 \\
\hline
\end{tabular}

TABLE II: Awareness about Record Keeping

\begin{tabular}{|c|c|c|c|c|c|}
\hline Questions & $\begin{array}{c}\mathrm{I} \\
\mathrm{N}=54 \\
\%\end{array}$ & $\begin{array}{c}\mathrm{R} \\
\mathrm{N}=118 \\
\%\end{array}$ & $\begin{array}{c}\mathrm{R} 2 \\
\mathrm{~N}=75 \\
\%\end{array}$ & $\begin{array}{c}\mathrm{R} 3 \\
\mathrm{~N}=53 \\
\%\end{array}$ & p-value \\
\hline $\begin{array}{l}\text { HOSPITAL IS LEGALLY BOUND TO MAINTAIN } \\
\text { RECORDS. }\end{array}$ & $\begin{array}{l}53 \\
98.1\end{array}$ & $\begin{array}{l}112 \\
94.9\end{array}$ & $\begin{array}{l}68 \\
90.7\end{array}$ & $\begin{array}{l}51 \\
96.2\end{array}$ & 0.56 \\
\hline $\begin{array}{l}\text { THE RECORD/FILE OF A PATIENT IS LEGALLY } \\
\text { HIS/HER PROPERTY. }\end{array}$ & $\begin{array}{l}40 \\
74.1\end{array}$ & $\begin{array}{l}91 \\
77.1\end{array}$ & $\begin{array}{l}51 \\
68\end{array}$ & $\begin{array}{l}40 \\
75.5\end{array}$ & 0.34 \\
\hline $\begin{array}{l}\text { HOW LONG DO YOU HAVE TO KEEP RECORDS OF } \\
\text { PATIENT IF IT IS A MEDICO-LEGAL CASE? }\end{array}$ & & & & & \\
\hline a) $\quad 2$ years & $\begin{array}{l}2 \\
3.7\end{array}$ & $\begin{array}{l}7 \\
5.9\end{array}$ & $\begin{array}{l}8 \\
10.7\end{array}$ & $\begin{array}{l}2 \\
3.8\end{array}$ & \\
\hline 3 years & $\begin{array}{l}11 \\
20.4\end{array}$ & $\begin{array}{l}14 \\
11.9\end{array}$ & $\begin{array}{l}20 \\
26.7\end{array}$ & $\begin{array}{l}4 \\
24.5\end{array}$ & \\
\hline 5years & $\begin{array}{l}27 \\
50\end{array}$ & $\begin{array}{l}36 \\
30.5\end{array}$ & $\begin{array}{l}20 \\
26.7\end{array}$ & $\begin{array}{l}4 \\
7.5\end{array}$ & \\
\hline Till the case is judged & $\begin{array}{l}14 \\
25.9\end{array}$ & $\begin{array}{l}61 \\
51.7\end{array}$ & $\begin{array}{l}27 \\
36\end{array}$ & $\begin{array}{l}34 \\
64.2\end{array}$ & 0.00 \\
\hline
\end{tabular}

TABLE III: Awareness about Informed Consent

\begin{tabular}{|c|c|c|c|c|c|}
\hline Questions & $\begin{array}{c}\mathrm{I} \\
\mathrm{N}=54 \\
\%\end{array}$ & $\begin{array}{c}\mathrm{R} \\
\mathrm{N}=118 \\
\%\end{array}$ & $\begin{array}{c}\mathrm{R} 2 \\
\mathrm{~N}=75 \\
\%\end{array}$ & $\begin{array}{c}\mathrm{R} 3 \\
\mathrm{~N}=53 \\
\%\end{array}$ & p-value \\
\hline $\begin{array}{l}\text { INFORMED CONSENT IS REQUIRED IF A PATIENT } \\
\text { HAS TO UNDERGO AN OPERATION. }\end{array}$ & $\begin{array}{l}54 \\
100\end{array}$ & $\begin{array}{l}111 \\
94.1\end{array}$ & $\begin{array}{l}69 \\
92 \\
\end{array}$ & $\begin{array}{ll}50 \\
94.3\end{array}$ & 0.625 \\
\hline $\begin{array}{l}\text { FACTORS TAKEN INTO CONSIDERSTION WHEN } \\
\text { CONSENT IS GIVEN :- a) age and c) mental status }\end{array}$ & $\begin{array}{l}12 \\
22.2\end{array}$ & $\begin{array}{l}7 \\
5.9\end{array}$ & $\begin{array}{l}12 \\
16.0\end{array}$ & $\begin{array}{l}11 \\
20.8\end{array}$ & 0.024 \\
\hline $\begin{array}{l}\text { DOCTORS AND NURSES SHOULD NOT REFUSE } \\
\text { TREATMENT IF PATIENT BEHAVES VIOLENTLY. }\end{array}$ & $\begin{array}{l}24 \\
44.4\end{array}$ & $\begin{array}{l}85 \\
72\end{array}$ & $\begin{array}{l}29 \\
38.7\end{array}$ & $\begin{array}{l}26 \\
49.1\end{array}$ & 0.00 \\
\hline $\begin{array}{l}\text { CHILDREN SHOULD NOT BE TREATED (EXCEPT } \\
\text { IN EMERGENCY) WITHOUT THE CONSENT OF } \\
\text { PARENT OR GUARDIAN. }\end{array}$ & $\begin{array}{l}51 \\
91.4\end{array}$ & $\begin{array}{l}104 \\
88.1\end{array}$ & $\begin{array}{l}70 \\
93.3\end{array}$ & $\begin{array}{l}44 \\
83\end{array}$ & 0.29 \\
\hline
\end{tabular}

TABLE IV: Knowledge and Awareness on Medical Negligence

\begin{tabular}{|l|l|l|l|l|l|}
\hline CARELESSLY LEAVING OBJECTS IN THE & 54 & 112 & 73 & 50 & 0.69 \\
$\begin{array}{l}\text { OPERATION SITE IN THE BODY IS A PUNISHABLE } \\
\text { ACT. }\end{array}$ & $100 \%$ & $94.9 \%$ & $97.3 \%$ & $94.3 \%$ & \\
\hline NOT ATTENDING A PATIENT DURING EMERGENCY & 54 & 112 & 73 & 50 & 0.69 \\
IS A PUNISHABLE ACT. & 100 & 94.9 & 97.3 & 94.3 & \\
\hline REFUSING TO TREAT A HIV PATIENT IS A & 40 & 89 & 66 & 47 & 0.011 \\
PUNISHABLE BY LAW. & 74.1 & 75.4 & 88 & 88.7 & \\
\hline MEDICAL NEGLIGENCE COMES UNDER & & & & & \\
\hline a) Criminal & 1 & 39 & 24 & 12 & \\
& 1.9 & 33.1 & 32 & 22.6 & \\
\hline
\end{tabular}


Knowledge and Awareness among interns and residents about medical law and negligence in a

\begin{tabular}{|c|c|c|c|c|c|}
\hline Civil & $\begin{array}{l}5 \\
9.3\end{array}$ & $\begin{array}{l}31 \\
26.3\end{array}$ & $\begin{array}{l}14 \\
18.7\end{array}$ & $\begin{array}{l}9 \\
17\end{array}$ & \\
\hline Consumer Protection Act & $\begin{array}{l}29 \\
53.7\end{array}$ & $\begin{array}{l}23 \\
19.5\end{array}$ & $\begin{array}{l}12 \\
16\end{array}$ & $\begin{array}{l}10 \\
18.9\end{array}$ & \\
\hline All of the above & $\begin{array}{l}19 \\
35.2\end{array}$ & $\begin{array}{l}25 \\
21.2\end{array}$ & $\begin{array}{l}25 \\
33.3\end{array}$ & $\begin{array}{l}22 \\
41.5\end{array}$ & 0.00 \\
\hline \multicolumn{6}{|l|}{$\begin{array}{l}\text { IF A NURSE MISPLACED A GUAGE PIECE IN THE } \\
\text { SURGICAL SITE WHICH WAS THEN SUTURED, WHO } \\
\text { WILL BE HELD REPONSIBLE? }\end{array}$} \\
\hline a) $\quad$ Resident & $\begin{array}{l}1 \\
1.9\end{array}$ & $\begin{array}{l}2 \\
1.7\end{array}$ & $\begin{array}{l}3 \\
4\end{array}$ & $\begin{array}{l}1 \\
1.9\end{array}$ & \\
\hline Nurse & $\begin{array}{l}0 \\
0\end{array}$ & $\begin{array}{l}10 \\
8.5\end{array}$ & $\begin{array}{l}6 \\
8.0\end{array}$ & $\begin{array}{l}2 \\
3.8\end{array}$ & \\
\hline Surgeon & $\begin{array}{l}18 \\
33.3\end{array}$ & $\begin{array}{l}35 \\
29.7\end{array}$ & $\begin{array}{l}18 \\
24\end{array}$ & $\begin{array}{l}18 \\
34\end{array}$ & \\
\hline Hospital administrator & $\begin{array}{l}0 \\
0\end{array}$ & $\begin{array}{l}7 \\
5.9\end{array}$ & $\begin{array}{l}1 \\
1.3\end{array}$ & $\begin{array}{l}2 \\
3.8\end{array}$ & \\
\hline b) and c) & $\begin{array}{l}25 \\
46.3\end{array}$ & $\begin{array}{l}28 \\
23.7\end{array}$ & $\begin{array}{l}23 \\
30.7\end{array}$ & $\begin{array}{l}7 \\
13.2\end{array}$ & 0.001 \\
\hline \multicolumn{6}{|l|}{ EUTHANASIA IS LEGAL IN INDIA. } \\
\hline $\begin{array}{l}\text { a) Yes, it is allowed after the provisions of organ } \\
\text { transplantation act. }\end{array}$ & $\begin{array}{l}35 \\
64.8\end{array}$ & $\begin{array}{l}56 \\
47.5\end{array}$ & $\begin{array}{l}29 \\
38.9\end{array}$ & $\begin{array}{l}29 \\
54.7\end{array}$ & 0.002 \\
\hline b) $\quad$ No & $\begin{array}{l}19 \\
35.2\end{array}$ & $\begin{array}{l}59 \\
50\end{array}$ & $\begin{array}{l}38 \\
48\end{array}$ & $\begin{array}{l}21 \\
39.6\end{array}$ & \\
\hline Not sure & $\begin{array}{l}0 \\
0\end{array}$ & $\begin{array}{l}3 \\
2.5\end{array}$ & $\begin{array}{l}10 \\
13.3\end{array}$ & $\begin{array}{l}3 \\
5.7\end{array}$ & \\
\hline $\begin{array}{l}\text { IF DOCTOR CAUSES DEATH OF PATIENT DUE TO } \\
\text { MEDICAL NEGLIGENCE, THE CASE IS JUDGED IN } \\
\text { CONSUMER COURT }\end{array}$ & $\begin{array}{l}53 \\
98.1\end{array}$ & $\begin{array}{l}101 \\
85.6\end{array}$ & $\begin{array}{l}67 \\
89.3\end{array}$ & $\begin{array}{l}48 \\
90.6\end{array}$ & 0.001 \\
\hline $\begin{array}{l}\text { PATIENT WANTS COMPENSATION FOR ANY } \\
\text { PROCEDURE THAT HAS GONE WRONG HE/SHE } \\
\text { APPROACHS THE CONSUMER COURT. }\end{array}$ & $\begin{array}{l}34 \\
63.3\end{array}$ & $\begin{array}{l}64 \\
54.2\end{array}$ & $\begin{array}{l}25 \\
33.3\end{array}$ & $\begin{array}{l}32 \\
60.4\end{array}$ & 0.00 \\
\hline ORGAN TRANSPLANTATIONIS IS LEGAL IN INDIA & $\begin{array}{l}54 \\
100\end{array}$ & $\begin{array}{l}103 \\
87.3\end{array}$ & $\begin{array}{l}60 \\
80\end{array}$ & $\begin{array}{l}49 \\
92.5\end{array}$ & 0.002 \\
\hline $\begin{array}{l}\text { ACCORDING TO ORGAN TRANSPLANTATIONS ACT, } \\
\text { ORGAN BY CAN BE DONATED? }\end{array}$ & & & & & 0.624 \\
\hline a) $\quad$ Blood relative & $\begin{array}{l}9 \\
16.7\end{array}$ & $\begin{array}{l}14 \\
11.9\end{array}$ & $\begin{array}{l}10 \\
13.3\end{array}$ & $\begin{array}{l}10 \\
18.9\end{array}$ & \\
\hline Cadaver & $\begin{array}{l}0 \\
0\end{array}$ & $\begin{array}{l}8 \\
6.8\end{array}$ & $\begin{array}{l}3 \\
4.0\end{array}$ & $\begin{array}{l}2 \\
3.8\end{array}$ & \\
\hline Spouse & $\begin{array}{l}0 \\
0\end{array}$ & $\begin{array}{l}2 \\
1.7\end{array}$ & $\begin{array}{l}2 \\
2.7\end{array}$ & $\begin{array}{l}1 \\
1.9\end{array}$ & \\
\hline All of the above & $\begin{array}{l}45 \\
83.3\end{array}$ & $\begin{array}{l}94 \\
79.7\end{array}$ & $\begin{array}{l}60 \\
80\end{array}$ & $\begin{array}{l}40 \\
75.5\end{array}$ & 0.624 \\
\hline
\end{tabular}

\begin{tabular}{|c|c|c|c|c|c|c|c|c|c|}
\hline & \multirow[b]{2}{*}{$N$} & \multirow[b]{2}{*}{ Mean } & \multirow[b]{2}{*}{ Std. Deviation } & \multirow[b]{2}{*}{ Std. Error } & \multicolumn{2}{|c|}{$\begin{array}{l}95 \% \text { Confidence Interval } \\
\text { for Mean }\end{array}$} & \multirow[b]{2}{*}{ Minimum } & \multirow[b]{2}{*}{$\begin{array}{l}\text { Maximu } \\
\quad m\end{array}$} \\
\hline & & & & & & $\begin{array}{l}\text { Lower } \\
\text { Bound }\end{array}$ & $\begin{array}{l}\text { Upper } \\
\text { Bound }\end{array}$ & & \\
\hline \multirow{5}{*}{$\begin{array}{c}\text { Record } \\
\text { Keepin } \\
\quad g\end{array}$} & Intern & 54 & 66.0494 & 17.72222 & 2.41169 & 61.2121 & 70.8866 & .00 & 100.00 \\
\hline & $R I$ & 118 & 74.5763 & 24.52898 & 2.25808 & 70.1043 & 79.0483 & .00 & 100.00 \\
\hline & $R 2$ & 75 & 64.8889 & 23.81947 & 2.75044 & 59.4085 & 70.3693 & .00 & 100.00 \\
\hline & $R 3$ & 53 & 78.6164 & 21.77423 & 2.99092 & 72.6146 & 84.6181 & 33.33 & 100.00 \\
\hline & Total & 300 & 71.3333 & 23.30226 & 1.34536 & 68.6858 & 73.9809 & .00 & 100.00 \\
\hline Ethics & Intern & 54 & 66.6667 & 29.13858 & 3.96526 & 58.7134 & 74.6200 & .00 & 100.00 \\
\hline
\end{tabular}


Knowledge and Awareness among interns and residents about medical law and negligence in a

\begin{tabular}{|cc|c|c|c|c|c|c|c|c|}
\hline & $R 1$ & 118 & 64.8305 & 36.57875 & 3.36735 & 58.1617 & 71.4994 & .00 & 100.00 \\
& $R 2$ & 75 & 63.3333 & 36.14286 & 4.17342 & 55.0176 & 71.6491 & .00 & 100.00 \\
& $R 3$ & 53 & 76.4151 & 31.93108 & 4.38607 & 67.6138 & 85.2164 & .00 & 100.00 \\
& Total & 300 & 66.8333 & 34.57780 & 1.99635 & 62.9047 & 70.7620 & .00 & 100.00 \\
\hline $\begin{array}{c}\text { Inform } \\
\text { ed }\end{array}$ & Intern & 54 & 60.1852 & 11.85900 & 1.61381 & 56.9483 & 63.4221 & 33.33 & 83.33 \\
$\begin{array}{c}\text { concer } \\
n\end{array}$ & $R 1$ & 118 & 61.4407 & 15.36191 & 1.41418 & 58.6400 & 64.2414 & 16.67 & 100.00 \\
& $R 2$ & 75 & 56.8889 & 14.77899 & 1.70653 & 53.4886 & 60.2892 & .00 & 83.33 \\
& $R 3$ & 53 & 61.0063 & 17.27833 & 2.37336 & 56.2438 & 65.7688 & .00 & 83.33 \\
\hline $\begin{array}{c}\text { Medic } \\
\text { al }\end{array}$ & Intern & 54 & 65.7407 & 13.33635 & 1.81485 & 62.1006 & 69.3809 & 42.86 & 92.86 \\
neglige & R1 & 118 & 60.2300 & 12.51125 & 1.15175 & 57.9490 & 62.5110 & 28.57 & 92.86 \\
nce & R2 & 75 & 65.0476 & 13.72316 & 1.58461 & 61.8902 & 68.2050 & 21.43 & 92.86 \\
& R3 & 53 & 62.6685 & 12.88775 & 1.77027 & 59.1162 & 66.2208 & 28.57 & 92.86 \\
& Total & 300 & 62.8571 & 13.17984 & .76094 & 61.3597 & 64.3546 & 21.43 & 92.86 \\
\hline
\end{tabular}

Table V: Descriptive Statistics of the Classes and Group

TABLE VI: One Way ANOVA

\begin{tabular}{|c|c|c|c|c|c|c|}
\hline & & Sum of Squares & $\mathrm{df}$ & Mean Square & $\mathrm{F}$ & Sig. \\
\hline \multirow[t]{3}{*}{ Record Keeping } & $\begin{array}{c}\text { Between } \\
\text { Groups }\end{array}$ & 8674.712 & & 2891.571 & 5.569 & .001 \\
\hline & Within Groups & 153680.844 & 296 & 519.192 & & \\
\hline & Total & 162355.556 & 299 & & & \\
\hline \multirow[t]{3}{*}{ Ethics } & $\begin{array}{l}\text { Between } \\
\text { Groups }\end{array}$ & 6259.522 & & & 1.758 & .155 \\
\hline & Within Groups & 351232.145 & 296 & 1186.595 & & \\
\hline & Total & 357491.667 & 299 & & & \\
\hline \multirow[t]{3}{*}{ Informed concern } & $\begin{array}{c}\text { Between } \\
\text { Groups }\end{array}$ & 1026.362 & 3 & 342.121 & 1.517 & .210 \\
\hline & Within Groups & 66751.416 & 296 & 225.512 & & \\
\hline & Total & 67777.778 & 299 & & & \\
\hline \multirow[t]{3}{*}{$\begin{array}{l}\text { Medical } \\
\text { negligence }\end{array}$} & $\begin{array}{c}\text { Between } \\
\text { Groups }\end{array}$ & 1625.175 & 3 & 541.725 & 3.187 & .024 \\
\hline & Within Groups & 50313.601 & 296 & 169.978 & & \\
\hline & Total & 51938.776 & 299 & & & \\
\hline
\end{tabular}

TABLE VII: Post Hoc test

\begin{tabular}{|c|c|c|c|}
\hline $\begin{array}{l}\text { Dependent } \\
\text { Variable }\end{array}$ & $\begin{array}{l}\text { (I) } \\
\text { group_code }\end{array}$ & $\begin{array}{l}\text { (J) } \\
\text { group_code }\end{array}$ & p-value \\
\hline \multirow{6}{*}{$\begin{array}{l}\text { Record } \\
\text { Keeping }\end{array}$} & \multirow[t]{3}{*}{ Intern } & R1 & .023 \\
\hline & & $\overline{\mathrm{R} 2}$ & .776 \\
\hline & & R3 & .005 \\
\hline & \multirow[t]{3}{*}{ R1 } & Intern & .023 \\
\hline & & R2 & .004 \\
\hline & & R3 & .284 \\
\hline & \multirow[t]{2}{*}{$\mathrm{R} 2$} & Intern & .776 \\
\hline & & R1 & .004 \\
\hline
\end{tabular}




\begin{tabular}{|c|c|c|c|}
\hline & & R3 & .001 \\
\hline & \multirow[t]{3}{*}{ R3 } & Intern & .005 \\
\hline & & R1 & .284 \\
\hline & & R2 & .001 \\
\hline \multirow{3}{*}{$\begin{array}{l}\text { Medical } \\
\text { negligence }\end{array}$} & \multirow[t]{3}{*}{ Intern } & R1 & .011 \\
\hline & & R2 & .766 \\
\hline & & R3 & .224 \\
\hline & \multirow[t]{3}{*}{ R1 } & Intern & .011 \\
\hline & & R2 & .013 \\
\hline & & R3 & .259 \\
\hline & \multirow[t]{3}{*}{ R2 } & Intern & .766 \\
\hline & & R1 & .013 \\
\hline & & R2 & .310 \\
\hline & \multirow[t]{3}{*}{ R3 } & Intern & .224 \\
\hline & & R1 & .259 \\
\hline & & R2 & .310 \\
\hline
\end{tabular}

\section{Conclusion}

The study was a genuine endeavor to assess the knowledge of medical interns and residents about ethics, record keeping, informed consent and medico-legal issues. The participants were knowledgeable about medical ethics and informed consent but when it came to record keeping and medical negligence their information was basic, they lacked knowledge about finer details. Local bodies and medical associations should increase their participation in holding seminars, CME's for the students to increase awareness of medico-legal issues in medical practice. The curriculum for students needs to be more detailed in regard to medico-legal aspects. . During residency, thorough literature review of malpractice cases should be considered compulsory and hospital cases with possible legal implications should be discussed. This will help the student to understand the medico-legal process and the ramifications attached to them. The limitation of our study is that it was conducted in one institute, even though the hospital consists of a diverse group of students coming from different backgrounds, it cannot predict the overall situation in the country.

\section{Acknowledgements}

We are thankful for the help of our interns in this study. We are am grateful to Dr. Vikas Doshi, Assistant Professor (Statistics), Department of PSM, Government Medical College, Vadodara for his help in statistical analysis of the data. Special thanks are due for Dr. Thanveer K., Professor, Department of Public Health Dentistry, K.M.S.D.C.H. for the critically appraisal of the paper.

\section{References}

[1] Dr. Kong-lung H., Law and Ethics in Medical Practice: An Overview, Medicine Section, 8(6), 2003, 3-7.

[2] [Mayeda M. and Takase K.., Need for enforcement of ethicolegal education - an analysis of the survey of postgraduate clinical trainees, BMC Medical Ethics, 6(8), 2005, Available at: http://www.biomedcentral.com/1472-6939/6/8 [Last cited on 2012 AUG 3].

[3] Dash S.K. [Medical Ethics, Duties \& Medical Negligence Awareness among the Practitioners in a Teaching Medical College, Hospital-A Survey, J Indian Acad Forensic Med, 32(2), 2010,153-156.

[4] Walrond ER, Jonnalagadda R, Hariharan S and Moseley HSL, Knowledge, attitudes and practice of medical students at the Cave Hill Campus in relation to ethics and law in healthcare, West Indian Med, 55 (1), 2006, 42-47.

[5] Makhani C.S., Petkar M. R., Chavan K.D., T.V. Rao, Indian Journal of Forensic Medicine and Pathology, 4(4), 2011, 151-155.

[6] Dhawan R, Dhawan S. Legal aspects in dentistry. J Indian Soc Periodontol 14, 2010, 81-4.

[7] Astekar M, Saawarn S, Ramesh G, Saawarn N., Maintaining dental records: Are we ready for forensic needs?, J Forensic Dent Sci 3, 2011, 52-7.

[8] Yousuf R M, Fauzi A R M, How S H, Rasool A G, Rehana K Awareness, knowledge and attitude towards informed consent among doctors in two different cultures in Asia: a cross-sectional comparative study in Malaysia and Kashmir, India, Singapore Med J, 48 (6), 2007, 559-565

[9] Heywood R., Macaskill A. and Williams K., Medical students' perceptions of informed consent: legal reflections on clinical education, Journal of professional negligence, 23 (3), 2007, 151-164.

[10] Joshi S.K., Law and the practice of medicine (New Delhi, Jaypee, 2010).

[11] Fox P. Medico-legal issues, Rural Collaborative Practice Project, Available from: http://health.vic.gov.au/ruralhealth/downloads/dlaphillips-fox.pdf [Last cited on 2012 Dec 24]

[12] Roberts L.W., Hammond K.A.G., Geppert C.M.A., Warner T. D., The Positive Role of Professionalism and Ethics Training in Medical Education: A Comparison of Medical Student and Resident Perspectives, Academic Psychiatry, 28(3), 2004, 170-182. 